\title{
Characterization of an iridovirus from the cultured pig frog Rana grylio with lethal syndrome
}

\author{
Qi-Ya Zhang ${ }^{1, *}$, Feng Xiao ${ }^{1}$, Zhen-Qiu Li ${ }^{1}$, Jian-Fang Gui ${ }^{1}$, Jinghe Mao ${ }^{2}$, \\ V. Gregory Chinchar ${ }^{2}$

\begin{abstract}
${ }^{1}$ State Key Laboratory of Freshwater Ecology and Biotechnology, Institute of Hydrobiology, Chinese Academy of Sciences, Wuhan 430072, China

${ }^{2}$ Department of Microbiology, University of Mississippi Medical Center, Jackson, Mississippi 39216, USA
\end{abstract}

\begin{abstract}
Three virus isolates, RGV-9506, RGV-9807 and RGV-9808, were obtained from cultured pig frogs Rana grylio undergoing lethal infections. Previously, the first isolate, RGV-9506, was shown to be an iridovirus based on ultrastructural and morphological studies. In the present study, the original isolate, along with 2 recent ones, were more extensively characterized by experimental infection studies, histopathology, electron microscopy, serological reactivity, gel electrophoresis of viral polypeptides and DNA restriction fragments, PCR amplification, and nucleic acid sequence analysis of the major capsid protein (MCP) gene. The 3 isolates were shown to be identical to each other, and very similar to FV3, the type species of the genus Ranavirus (family Iridoviridae). These results suggest that RGV should be considered a strain of FV3, and indicate that FV3-like iridoviruses are capable of causing widespread, severe disease among cultured frogs.
\end{abstract}

KEY WORDS: Rana grylio $\cdot$ Iridovirus $\cdot$ FV3 $\cdot$ Ranavirus $\cdot$ Viral disease

\section{INTRODUCTION}

The pig frog Rana grylio was introduced into Chinese aquaculture in the 1980s. However since about 1995, frog aquaculture has been adversely impacted by an infectious agent (Zhang et al. 1996b, Zhang 1997). Frog culture farms located in Hubei Province and Hunan Province have experienced significant disease, and mortality rates approaching over $90 \%$ have been observed. In an earlier study, a pathogenic virus, provisionally designated RGV-9506 (Rana grylio virus), was isolated from diseased pig frogs (Zhang et al. 1996a), and was suggested to be an iridovirus based on ultrastructural analysis of virions and morphological studies of infected epithelioma papulosum cyprini (EPC) cells (Zhang et al. 1999b). Large, icosahedral virus particles were detected diffusely distributed in the nucleus, cytoplasm and on the cell surface, and were abundant within cytoplasmic paracrystalline arrays. In addition, other iridovirus features such as the

*E-mail: jfgui@ihb.ac.cn presence of viral assembly sites (viromatrix) and viral budding from the plasma membrane, were also observed. Based on these similarities, RGV was suggested to be a member of the family Iridoviridae (Zhang et al. 1999b).

Iridoviruses have been isolated from amphibian (Granoff et al. 1966, Essani \& Granoff 1989, Speare \& Smith 1992, Alves de Matos \& Paperna 1993, Hengstberger et al. 1993, Cunningham et al. 1995, Drury et al. 1995, Zupanovic et al. 1998a,b, Bollinger et al. 1999) and fish hosts (Ahne et al. 1989, 1997, Essani \& Granoff 1989, Hedrick et al. 1992, Hedrick \& McDowell 1995, Granzow et al. 1997, Tapiovaara et al. 1998, Watson et al. 1998, Whittington et al. 1999) and have been associated with high mortality in some species (Langdon et al. 1986, 1988, Fijan et al. 1991, Cullen et al. 1995, Drury et al. 1995, Matsuoka et al. 1996, Rodger et al. 1997, Kanchanakhan 1998, McGrogan et al. 1998). For example, epizootic hematopoietic necrosis virus (EHNV), first isolated in Victoria, Australia, is responsible for large-scale mortalities in redfin perch Perca fluviatilis due to necrosis of hepatic, splenic, pancre- 
atic, and renal hematopoietic tissues. Moreover, although infection of redfin perch leads to high levels of mortality, EHNV infects other fish species with varying results (Langdon et al. 1986). In another example, localized die-offs of tiger salamanders Ambystoma tigrinum and largemouth bass Micropterus salmoides in North America have been linked to the presence of novel iridoviruses (Plumb et al. 1996, Jancovich et al. 1997, Bollinger et al. 1999). Finally, iridoviruses can infect not only different species within the same taxonomic class, but the same virus can infect animals from different classes (Mao et al. 1999a). Thus, an iridovirus isolated from the ornate burrowing frog Bohle iridovirus has been shown to cause mortality in barramundi fish following experimental infections (Moody \& Owens 1994). The above observations indicate that iridoviruses infecting aquatic animals enjoy a worldwide distribution and are increasingly associated with serious disease (Ahne et al. 1997, Hyatt et al. 2000).

Although some aspects of iridovirus biology have been examined (Willis et al. 1985, Hedrick et al. 1992, Nakajima et al. 1998, Zupanovic et al. 1998a,b, Bollinger et al. 1999, Mao et al. 1999a,b), additional work is needed to understand the ecology, epidemiology, and pathogenicity of iridovirus-host interaction. In this study, 3 RGV isolates linked to severe disease in cultured frogs were characterized by experimental infection, histopathology, electron microscopy, serological cross reactivity, gel electrophoresis of virion polypeptides and DNA restriction fragments, PCR amplification, and sequence analysis of the major capsid protein (MCP) gene. We found that the 3 isolates were essentially identical to each other and closely related to FV3. In view of this, it is likely that RGV is a strain of FV3.

\section{MATERIALS AND METHODS}

Preparation of RGV isolates. RGV isolates were prepared from tissues (liver, kidney and spleen) of diseased pig frogs with lethal syndrome (Zhang et al. 1996a). Briefly, liver, kidney and spleen were cut into pieces and homogenized in phosphate-buffered saline (PBS) containing antibiotics (penicillin, $100 \mathrm{IU} \mathrm{ml}^{-1}$; streptomycin, $100 \mu \mathrm{g} \mathrm{ml} \mathrm{m}^{-1}$ ). Extracts were stored overnight at $-20^{\circ} \mathrm{C}$, thawed, clarified by low speed centrifugation, and the resulting supernatants containing RGV stored at -80 or $-20^{\circ} \mathrm{C}$. The first isolate, RGV9506, was prepared from diseased young frogs (weight, about $20 \mathrm{~g}$ ) from a frog culture farm located in Wuhan, Hubei province (Zhang et al. 1996a,b), whereas RGV-9807 and RGV-9808 were isolated in 1998, respectively, from diseased adult frogs (weight, about $300 \mathrm{~g}$ ) and tadpoles (weight, about $10 \mathrm{~g}$ ) from 2 different frog culture farms. One farm was located in
Table 1. Sources of the virus isolates used in this study

\begin{tabular}{|c|c|c|c|}
\hline Isolates & Hosts & $\begin{array}{l}\text { Year of } \\
\text { isolation }\end{array}$ & Location \\
\hline RGV9506 & $\begin{array}{c}\text { Young frogs } \\
\text { after metamorphosis }\end{array}$ & 1995 & $\begin{array}{l}\text { Wuhan, } \\
\text { Hubei province }\end{array}$ \\
\hline RGV9807 & Adult frogs & 1998 & $\begin{array}{c}\text { Yueyang, } \\
\text { Hunan province }\end{array}$ \\
\hline RGV9808 & Tadpoles & 1998 & $\begin{array}{c}\text { Wuhan, } \\
\text { Hubei province }\end{array}$ \\
\hline
\end{tabular}

Yueyang, Hunan province, and the other in Wuhan, Hubei province (Table 1).

Cell infection and virus propagation. Four cell lines, EPC, EG (eel gonad), GCO (grass carp ovary) and GCF (grass carp fin), were used for viral sensitivity tests (Zhang 1997, Zhang \& Li 1999). The cells were grown to confluence in $25 \mathrm{~cm}^{2}$ cell culture flasks at $25^{\circ} \mathrm{C}$ in 199 medium supplemented with $10 \%$ fetal bovine serum. For virus propagation, each cell culture flask was infected with $1 \mathrm{ml}$ virus isolate at $10^{5} \mathrm{TCID}_{50} \mathrm{ml}^{-1}$ and incubated at $25^{\circ} \mathrm{C}$ until cytopathic effect (CPE) was complete (Zhang et al. 1996a,b, 1997, 1999b).

Experimental infection of frogs. Healthy tadpoles and young frogs, with a mean weight of about $20 \mathrm{~g}$, were collected from a culture farm with no previous history of disease. The frogs were transferred to $0.25 \mathrm{~m}^{3}$ tanks (20 specimens/tank) with cycling water and maintained at 25 to $30^{\circ} \mathrm{C}$. The population was divided into experimental and control groups. Tadpoles and frogs in the experimental groups were challenged by intraperitoneal injection with $0.2 \mathrm{ml}$ of original RGV isolates or $0.2 \mathrm{ml}$ propagated virus isolates from infected cells. For infection experiments, the RGV preparations were generally adjusted to about $10^{5}$ TCID $_{50} \mathrm{ml}^{-1}$. Tadpoles and frogs in control groups were intraperitoneally injected with $0.2 \mathrm{ml}$ of PBS.

Preparation of tissue specimens. Liver, spleen, kidney, lung and intestine were examined. Control and infected frogs were sampled $2 \mathrm{wk}$ post infection. Tissue specimens were fixed in phosphate buffered $10 \%$ formalin for light microscope and histopathology. Samples were embedded in paraffin, $5 \mu \mathrm{m}$ sections cut, stained with Meyer's hematoxylin and eosin (H\&E), and examined by light microscopy.

Transmission electron microscopic observation. EPC cells infected with different virus isolates were fixed with $2 \%$ glutaraldehyde, post-fixed in osmium tetroxide $\left(\mathrm{OsO}_{4}\right)$, dehydrated and embedded in Epon812. Ultrathin sections were cut and stained with $2 \%$ uranyl acetate and lead citrate, and examined with a Hitachi H-7000 electron microscope.

DNA fragmentation assay. Infected cells were harvested at 1 to $12 \mathrm{~h}$ after infection with RGV. Infected 
cells were lysed in $10 \mathrm{mM}$ Tris-HCl, pH7.4; $1 \mathrm{mM}$ EDTA, $0.2 \%$ Triton X-100, and collected by centrifugation at $11000 \times g$. Fragmented DNA present in the supernatants was separated by electrophoresis on $1.2 \%$ agarose gels, and visualized by ultraviolet light after staining with ethidium bromide (Uckun et al. 1996, Zhang et al. 1999a).

Isolation and purification of virus particles. Stock virus suspensions were prepared by propagating virus isolates in EPC cells using TC 199 medium supplemented with $10 \%$ fetal bovine serum and incubated at $25^{\circ} \mathrm{C}$. Following complete development of $\mathrm{CPE}$, cell culture fluids were harvested and cell debris removed by centrifugation at $8000 \mathrm{rpm}(7000 \times g)$ for $20 \mathrm{~min}$, the supernatant was ultracentrifuged in a Beckman (rotor type, SW41) at $38000 \mathrm{rpm}(90000 \times g)$ for $40 \mathrm{~min}$. The pellet was resuspended in $1 \mathrm{ml}$ PBS and further purified by using discontinuous sucrose $(20,30,40$ and $50 \%)$ gradient centrifugation at $38000 \mathrm{rpm}(90000 \times \mathrm{g})$ for $40 \mathrm{~min}$. The virus particle band was collected, and sucrose was removed by further centrifugation. The resulting pellet from each $100 \mathrm{ml}$ of cell culture fluid was resuspended in $1 \mathrm{ml}$ of PBS for preparation of immune sera or in $1 \mathrm{ml}$ of TE buffer for analysis of structural polypeptides and molecular characterization. The purified virus particles were stored at $-20^{\circ} \mathrm{C}$ until use.

Preparation of immune sera. Rabbits were intraperitoneally injected with $1 \mathrm{ml}$ of a 1:1 mixture of purified RGV-9506, RGV-9807 or RGV-9808 particles suspended in PBS and Freund's complete adjuvant. After 6 successive weekly injections, the rabbits were bled and serum was collected $1 \mathrm{wk}$ following the final injection. Sera were stored at $-20^{\circ} \mathrm{C}$ until use.

Immunodiffusion and neutralization assays. Immunodiffusion was performed in $0.5 \%$ agarose gels as described by Bailey (1996) and Zhang et al. (2000b). Rabbit antiserum raised against RGV-9506, RGV-9807 or RGV-9808 was added to the center well, and the 3 isolates (RGV-9506, RGV-9807 and RGV-9808) along with FV3, grass carp reovirus (GCV), and the shrimp virus Penaeus monodon baculovirus (MBV) (Jiang et al. 1995, Zhang et al. 1998) were placed into the surrounding wells. Immunodiffusion reactions were incubated for $2 \mathrm{~d}$. Neutralization assays were performed with each of the rabbit sera by CPE reduction tests. Briefly, virus isolates $\left(10^{4} \mathrm{TCID}_{50} /\right.$ well $)$, incubated in the presence or absence of 2 -fold serial dilutions of the different antibodies, were inoculated onto GCO cell monolayers grown in 96-well dishes, and the ability of antisera to block CPE was monitored.

Analysis of structural polypeptides. From each sample, $10 \mu \mathrm{l}$ of purified virus particles were dissolved in loading buffer $(50 \mathrm{mM}$ Tris- $\mathrm{HCl}[\mathrm{pH} 6.8], 100 \mathrm{mM}$ dithiothreitol, $2 \%$ SDS, $0.1 \%$ bromophenol blue, $10 \%$ glycerol) and boiled at $100^{\circ} \mathrm{C}$ for 5 min. Polypeptides were separated by electrophoresis on $15 \%$ SDS-PAGE gels using a Mini-Protein II electrophoresis system (Bio-Rad) as described previously (Gui et al. 1994). The bands were visualized using Coomassie brilliant blue.

Restriction endonuclease digestion of viral genomic DNA. As described previously (Zhang et al. 2000a), genomic DNA was isolated from $0.1 \mathrm{ml}$ of virus particles purified from infected cells and digested with HindIII. Digested DNA was separated on $1 \%$ agarose gels, visualized by staining with ethidium bromide, and photographed under UV illumination.

PCR amplification of viral DNA. Viral DNA isolated from infected cells was used as template and amplified using oligonucleotide primers targeted to the $5^{\prime}$ terminus of the iridovirus MCP gene (forward primer: 5'GACTTGGCCACTTATGAC3'; reverse primer, 5'GTCTCTGGAGAAGAAGAA3', Mao et al. 1999b). Briefly, $1 \mu \mathrm{l}(0.3$ to $0.5 \mu \mathrm{g})$ of viral DNA was amplified in a $50 \mu \mathrm{l}$ reaction mixture containing $50 \mathrm{mM} \mathrm{NaCl}$, $10 \mathrm{mM}$ Tris-HCI pH 9.3, $3 \mathrm{mM} \mathrm{MgCl} 2,40 \mu \mathrm{M}$ tetramethylammonium chloride, $200 \mu \mathrm{M}$ of each dNTP, $340 \mathrm{ng}$ of each primer, and 2.5 U Taq DNA polymerase (P/E, Ampli-Taq Gold). Cycling conditions were: $94^{\circ} \mathrm{C} / 5 \mathrm{~min}(1 \mathrm{cycle}) ; 94^{\circ} \mathrm{C} / 1 \mathrm{~min}, 45^{\circ} \mathrm{C} / 2 \mathrm{~min}, 55^{\circ} \mathrm{C} /$ 3 min ( 28 cycles); $72^{\circ} \mathrm{C} / 2$ min (1 cycle). Amplified DNA was separated by electrophoresis on $0.7 \%$ agarose gels and visualized by ethidium bromide staining.

Nucleic acid sequence analysis. PCR products were cloned into pCR2.1 (Invitrogen) and plasmid DNA bearing iridovirus inserts was isolated and used as template for sequence analysis. Both DNA strands from 2 independent subclones of RGV-9807 and -9808 were sequenced by cycle sequencing using the SequiTherm EXCEL II Long-Read Sequencing Kit LC (Epicenter Technologies, Madison, WI) and vectorspecific M13 forward and reverse primers labeled with IRD-800, an infrared fluorophore. Sequence reactions were analyzed using a Li-Cor Model 4000L automated DNA sequencer. Sequences from both strands were compiled, edited and compared using DNASIS version 2.5 (Hitachi Software, South San Francisco, CA, USA). Multiple alignment of the inferred amino acid sequences was performed using the MEGALIGN program within DNASTAR (Madison, WI, USA).

\section{RESULTS}

\section{Symptoms of diseased frogs}

Infected tadpoles and young frogs exhibited symptoms beginning 1 to $2 \mathrm{wk}$ after experimental injection with RGV. In tadpoles undergoing metamorphosis, purplish red spots first appeared on the legs, then hem- 


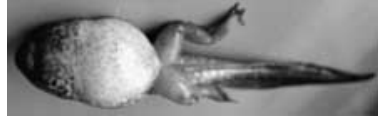

A

B

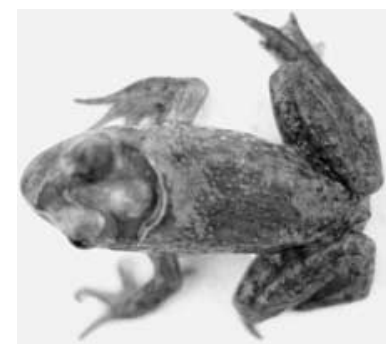

Fig. 1. Rana grylio. (A) RGV infected tadpole and (B) young frog with severe hemorrhagic symptoms. Purplish red spots and hemorrhages appeared on legs of the tadpole undergoing metamorphosis (A). Back skin had ulcerated on the young frog, and hemorrhagic spots were observed on the ulcerated skin (B)

orrhages occurred throughout the leg area (Fig. 1A). For young frogs, hemorrhagic spots appeared around neck, back and abdomen, and the skin began to ulcerate (Fig. 1B). As the disease progressed and the symptoms became more extensive, diffuse hemorrhagic spots became more obvious. Numerous hemorrhagic spots on the liver and other tissues could be observed after dissection. Death began about 1 wk after infection, and mortality approached $95 \%$ after $2 \mathrm{wk}$ (Table 2). Symptoms and lethality induced by the 3 virus isolates were identical to each other, and were similar to those seen in diseased frogs from frog culture farms (Zhang et al. 1996a).

\section{Histopathological changes in infected frogs}

Histopathological changes were investigated in 6 organs, including liver, spleen, kidney, heart, intestine, and lung from the infected frogs, and compared with corresponding organs from normal control individuals.

Fig. 2. Rana grylio. Histopathological changes in 6 organs, including (A) liver, (B) spleen, (C) kidney, (D) heart, (E) intestine, and (F) lung. Left panels: uninfected healthy controls; right panels: diseased tissues showing histopathological changes. $\times 20$

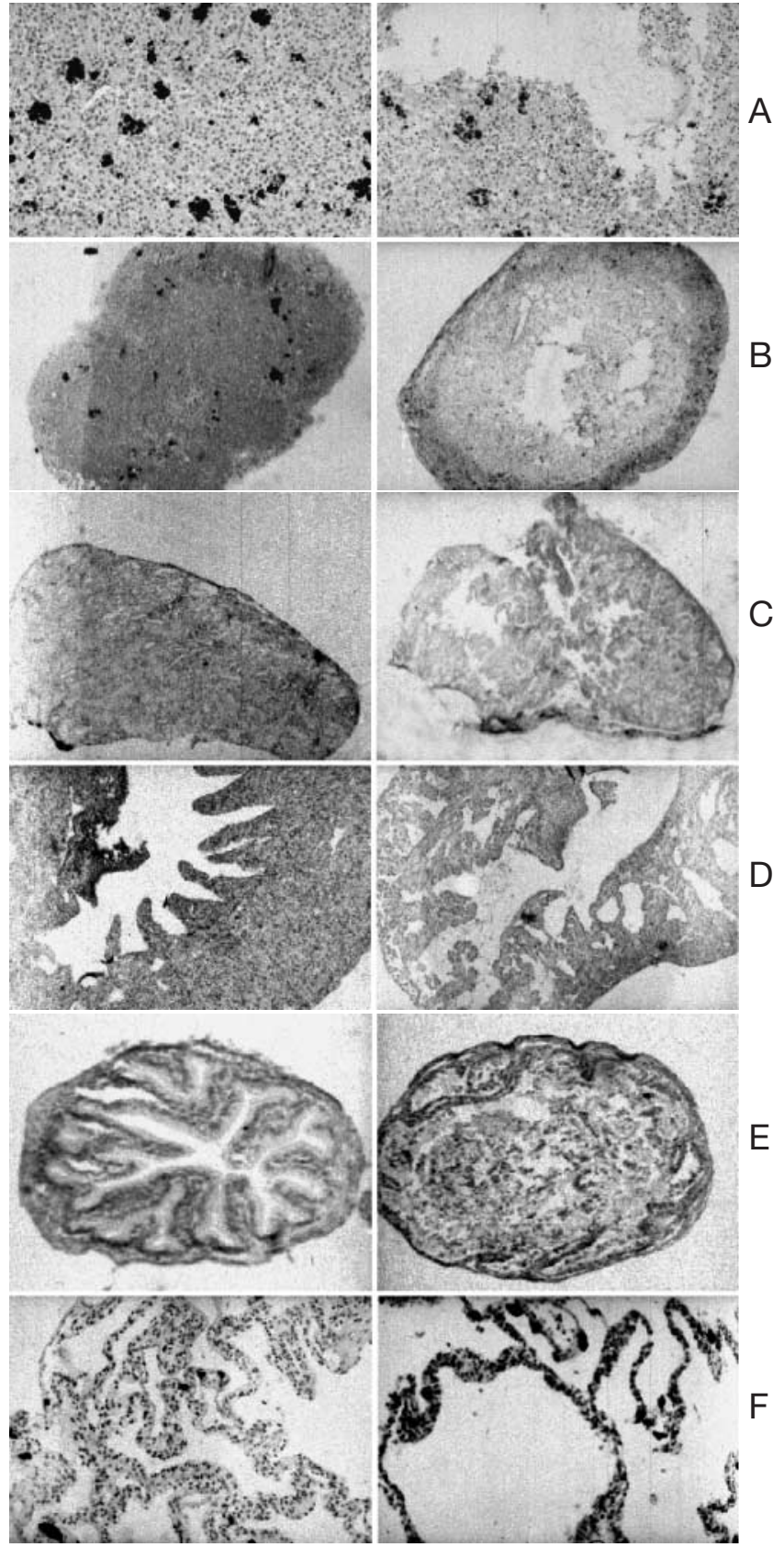

Table 2. Mortality of tadpoles and young frogs caused by experimental infection with RGV

\begin{tabular}{|lccccc|}
\hline & Tadpoles & Host (virus isolate) & & Frogs \\
(RGV-9506) & Frogs & $\begin{array}{c}\text { Frogs } \\
\text { (RGV-9506) }\end{array}$ & $\begin{array}{c}\text { Control } \\
\text { (RGV-9807) }\end{array}$ & (RGV-9808) & 20 \\
No. of injected individuals & 40 & 40 & 20 & 4 & 0 \\
No. of deaths after 1 wk & 1 & 2 & 2 & 16 & 0 \\
No. of deaths after 2 wk & 36 & 36 & 17 & 20 & 0 \\
Total no. of deaths & 37 & 38 & $95 \%$ & $100 \%$ & 0 \\
Mortality & $92.5 \%$ & $95 \%$ & & 0 \\
\hline
\end{tabular}




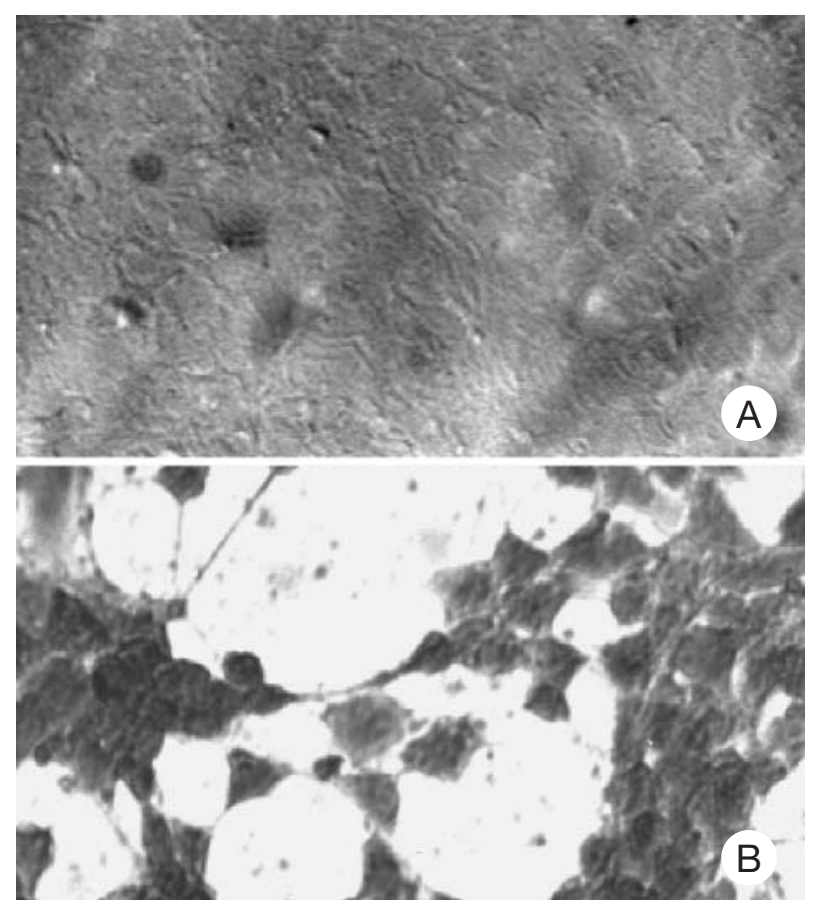

Fig. 3. RGV-induced cytopathic effect in infected GCO cells. (A) Uninfected control cultures; (B) infected cells. $\times 100$

The tissues examined showed various degrees of damage and necrosis. Numerous cells had broken down and cell arrangement within tissues was disrupted. Various size cavities were formed within the liver (Fig. 2A) and spleen (Fig. 2B). Epithelial cells in basal areas of the renal tubules became necrotic, and many renal tubules were broken (Fig. 2C). In heart tissue of infected frogs, muscle fibers were markedly atrophied and necrotic. Some normal heart tissue disappeared, and was replaced by fibrous material containing hemocytes (Fig. 2D). Lung tissue showed obvious damage, and the lobes became confused (Fig. 2F). The intestinal villi were extensively swollen, and numerous necrotic cells and blood cells were present within the intestinal cavity (Fig. 2E).

\section{Cytopathology within infected cells}

RGV isolates induced typical iridovirus CPE in all 4 cell lines (EPC, EG, GCO and GCF) examined. CPE was observed by light microscopy 10 to $12 \mathrm{~h}$ after virus infection. Under similar infection conditions, GCO cells were the most sensitive to infection. The temperature range for virus replication was 20 to $30^{\circ} \mathrm{C}$, and the optimum temperature was $30^{\circ} \mathrm{C}$ described previously (Zhang et al. 1996a). Some differences in cytopathology could be observed in the 4 infected cell lines. For example, infected GCO cells initially aggregated, and many small plaques were observed at low magnification. As cells lysed, the plaques enlarged (Fig. 3).

\section{Electron microscopic analysis of RGV isolates}

EM analysis of isolate RGV-9506 has been reported previously (Zhang et al. 1996a,b, 1999b). Comparative studies described in this report indicate that the isolates RGV-9807 and RGV-9808 were identical to RGV9506 in size and morphology. All are icosahedral enveloped particles with a diameter of approximately $150 \mathrm{~nm}$. As with FV3, most of the intracellular virus particles were present within paracrystalline arrays (Fig. 4).

\section{Cellular DNA fragmentation following viral infection}

Assays of cellular DNA integrity revealed marked DNA fragmentation in cells infected by RGV. By $8 \mathrm{~h}$ post infection, ladder-like DNA fragmentation patterns were readily visualized in infected cells (Fig. 5). The presence of characteristic DNA fragmentation patterns (i.e. a 200 bp DNA ladder) suggest that cell death following RGV infection might be due to apoptotic events, and is consistent with events in FV3-infected fathead minnow cells (V. G. Chinchar, G. D. Chinchar, J. Wang unpubl. obs.).
Fig. 4. Electron micrographs of intracellular viral inclusions. Isolates (A) RGV-9506, (B) RGV-9807, and (C) RGV-9808. $\times 15000$
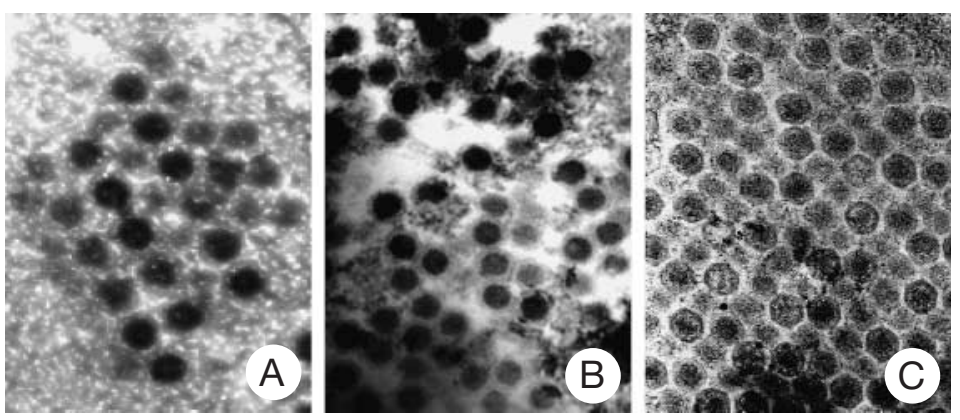


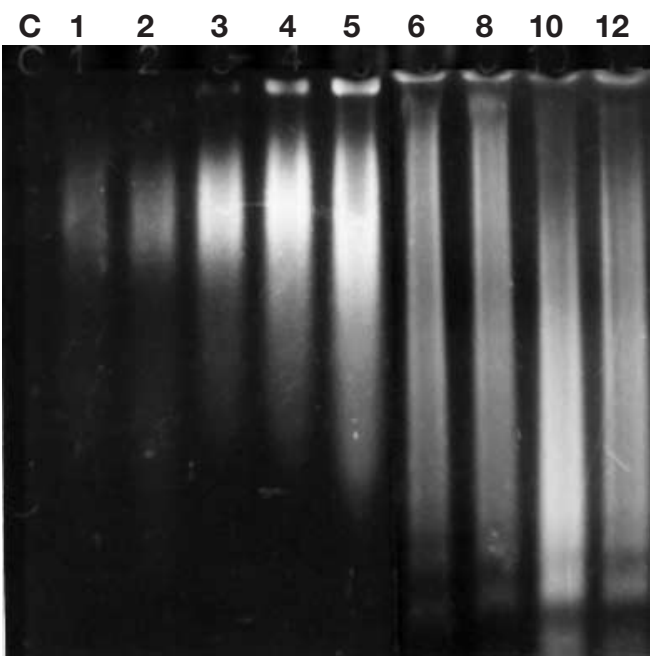

Fig. 5. Eletrophoretic separation of cellular DNA prepared from infected cells at various times $(1,2,3,4,6,8,10$, and $12 \mathrm{~h})$ after infection. C: DNA from the mock-infected cells

\section{Serological cross-reactivity among RGV isolates and FV3}

Immunodiffusion assays demonstrated obvious cross-reactivity among the $3 \mathrm{RGV}$ isolates. As shown in Fig. 6, precipitin lines were clearly observed not only between the anti-RGV-9506 serum and the isolates RGV-9506, -9807, and -9808, between the anti-RGV9807 serum and the isolates RGV-9506, -9807, and -9808, and between the anti-RGV-9808 serum and the isolates RGV-9506, -9807, and -9808 (Fig. 6A,B), but also between the anti-RGV serum and FV3 (Fig. 6B), whereas no immune complexes were detected between the antiserum and GCV or MBV (Fig. 6B). Neutralization assays confirmed the above immunodiffusion results, i.e. addition of antiserum raised against 1 isolate inhibited CPE induced by all 3 isolates (Fig. 6C, and data not shown). Taken together, the above results indicate that RGV isolates -9506, -9807, and -9808 were serologically identical to each other and to FV3.

\section{Analysis of viral structural polypeptides}

SDS-PAGE of purified virus particles indicated that the polypeptide profiles of the $3 \mathrm{RGV}$ isolates resembled each other and also that of FV3 (Fig. 7). Altogether, more than 16 different protein bands were visualized in each virus isolate. Moreover, although most of the bands were similar, some differences in band intensity were detected between the isolates. For example, the $49 \mathrm{kDa} \mathrm{MCP}$ band of FV3 was more intense than the corresponding band from the RGV isolates (Fig. 7).

\section{Molecular characterization}

As shown in Fig. 8A, electrophoretic patterns of restriction fragments obtained from the $3 \mathrm{RGV}$ isolates following digestion of viral DNA with HindIII were identical to each other and similar to that of FV3. Interestingly, there was only a single band difference from that of FV3, i.e. RGV isolates lack the $8.9 \mathrm{~kb}$ band seen in digests of FV3 DNA. Furthermore, PCR amplification of sequences within the $5^{\prime}$ end of the MCP gene generated a PCR product of $\sim 500$ nucleotides using DNA from FV3, RGV-9506, RGV-9807, and RGV-9808 (Fig. 8B).

Amplified DNA fragments from RGV-9506 and RGV9807 were cloned into the vector pCR2.1, and the nucleic acid sequence of the inserted PCR product determined. A multiple alignment of the deduced

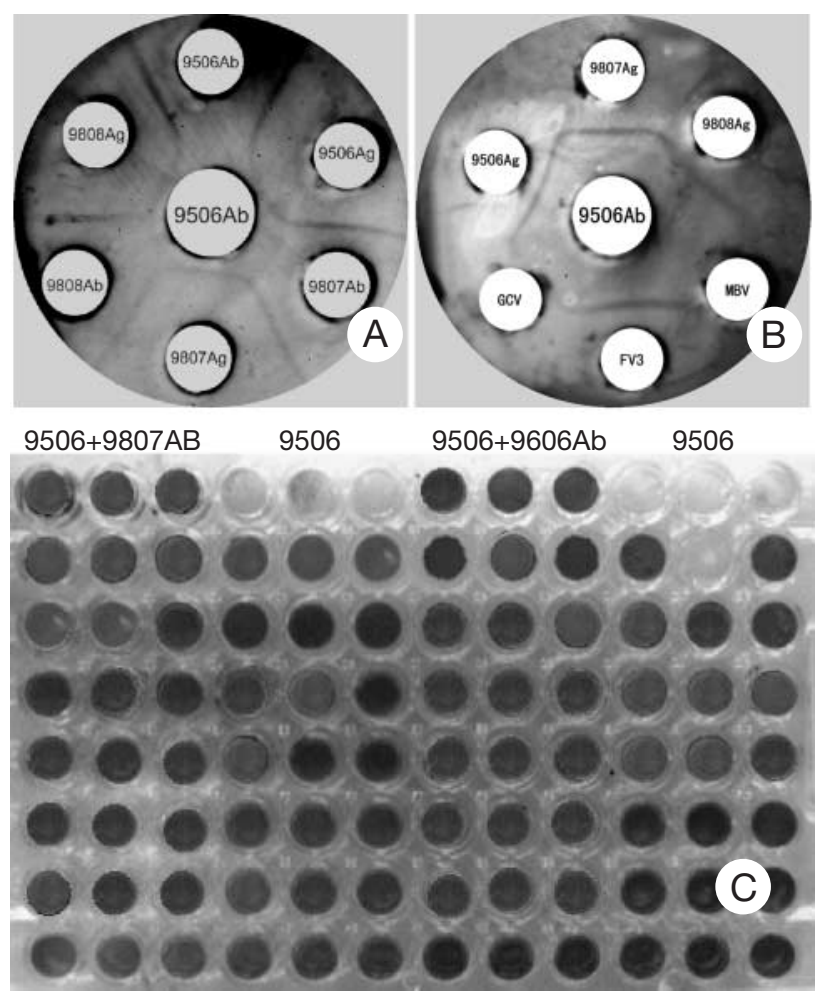

Fig. 6. Serological cross-reactivity of anti-RGV sera. (A) Immunodiffusion assay between 3 RGV antisera and the 3 RGV isolates. Precipitin lines were obvious between the anti-RGV9506 serum and the isolates RGV-9506, -9807, and -9808, between the anti-RGV-9807 serum and the isolates RGV9506, -9807, and -9808, and between the anti-RGV-9808 serum and the isolates RGV-9506, -9807, and -9808 respectively. (B) Immunodiffusion assay of anti-RGV-9506 serum (center well) versus the $3 \mathrm{RGV}$ isolates, FV3, GCV, and MBV. Precipitin lines were clearly observed between the anti-RGV serum and the RGV isolates, and between the anti-RGV serum and FV3. (C) Neutralization assay of RGV antiserum and RGV isolates. Neutralization effects of RGV-9506 antiserum and RGV-9807 antiserum on RGV-9506 were revealed 


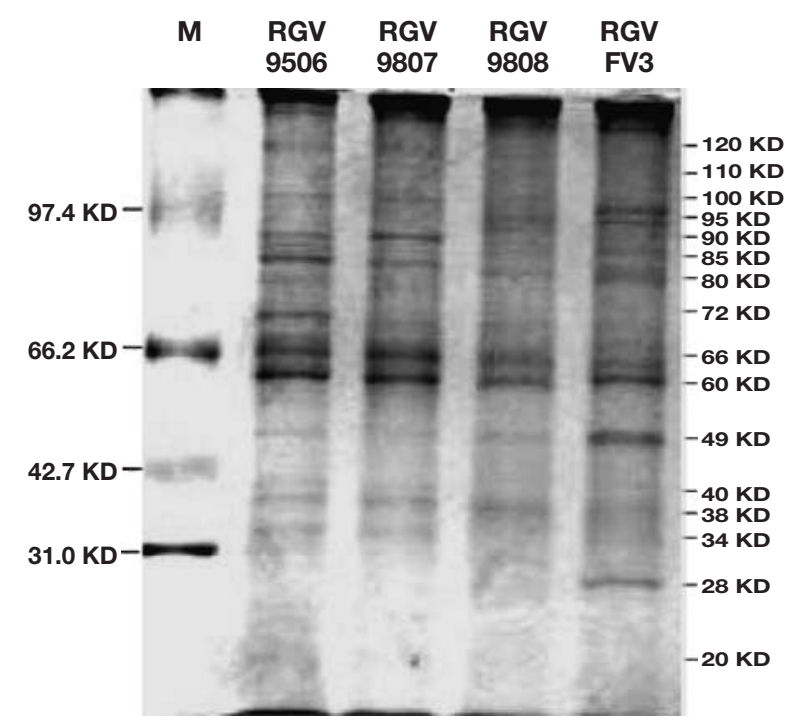

Fig. 7. SDS-PAGE analysis of structural proteins of the 3 RGV isolates and FV3. The 16 structural protein bands are indicated on the right side of the figure; standard molecular weight (MW) markers are shown on the left

amino acid sequences of the RGV products along with corresponding sequences from FV3 and other iridoviruses is shown in Fig. 9. At the amino acid level, the 2 Chinese isolates, RGV-9506 and RGV-9807, are identical to each other and differ from FV3 at only 1 position. Moreover, although the deduced amino acid sequences of RGV-9506 and RGV-9807 are identical, they differ from each other by a single nucleotide change. The change is seen in both molecular subclones, suggesting that it is not a PCR artifact and represents microheterogeneity in the virus population. In addition to their near identity with FV3, multiple alignment indicated that the RGV isolates shared, respectively, 94 and $81 \%$ identity with Regina ranavirus (RRV) and largemouth bass virus (LMBV), 2 viruses within the genus Ranavirus, and $50 \%$ identity to lymphocystis disease virus (LCDV) (genus Lymphocystivirus) (Fig. 9).

\section{DISCUSSION}

Previous ultrastructural and morphological studies showed that RGV-9506, isolated from cultured pig frogs Rana grylio undergoing a lethal infection (Zhang et al. 1996a), was a member of the family Iridoviridae (Zhang et al. 1999b). In 1998, 2 other isolates, RGV9807 and RGV-9808, were obtained from adult frogs and tadpoles with a similar clinical presentation. In this study, the $3 \mathrm{RGV}$ isolates were analyzed using a variety of approaches, e.g. experimental infections, histopathology, electron microscopy, serology, gel electrophoresis of virion polypeptides, restriction endonuclease digestion of the viral genome, PCR amplification, and nucleic acid sequence analysis of the MCP gene. In addition, when the $3 \mathrm{RGV}$ isolates were compared with FV3, the type species of the Ranavirus genus (family Iridoviridae), a high degree of identity with respect to morphology, serology, polypeptide
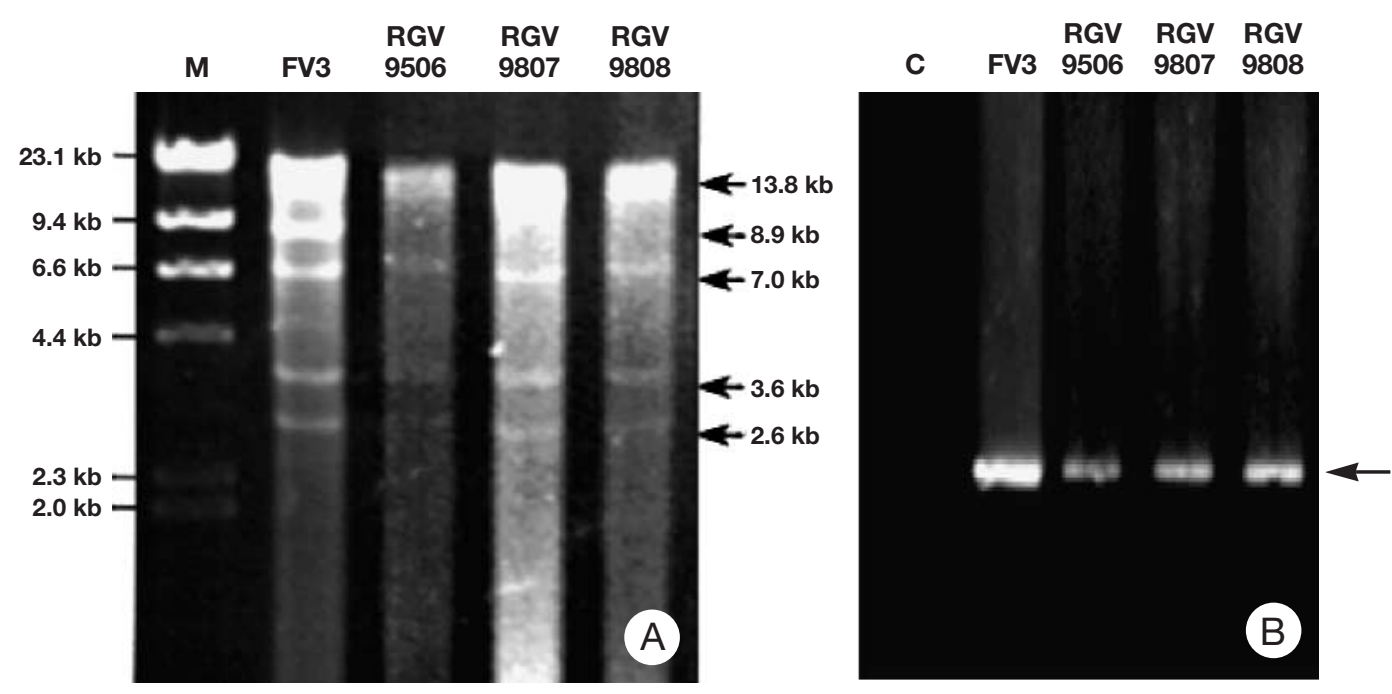

Fig. 8. Molecular characterization of virus isolates. (A) Comparison of HindIII restriction fragments of viral genomic DNA from the 3 RGV isolates and FV3. Genomic DNA was extracted from $0.1 \mathrm{ml}$ of the purified virus particles of the indicated RGV isolates and digested with HindIII. Digested DNA was separated on a $1 \%$ agarose gel and visualized by staining with ethidium bromide. Sizes of the marker fragments are shown to the left, and the main restriction fragments and their sizes are indicated by arrows on the right. (B) Amplification products of MCP gene from the 3 RGV isolates and FV3. Purified virus genomic DNA was used as template in PCR reactions described in 'Materials and methods'. PCR products were separated on a $1 \%$ agarose gel and visualized by staining with ethidium bromide. The approximate $500 \mathrm{bp}$ band is indicated by an arrow 


\begin{tabular}{l|l}
\multicolumn{1}{c}{10} \\
1
\end{tabular}

Fig. 9. Multiple alignment of the deduced amino acid sequence of the major capsid protein gene (MCP) from RGV-9506 and RGV-9807 along with other members of the family Iridoviridae. The sequence of the MCP gene of RGV isolates 9506 and 9807 was determined as described in 'Materials and methods'. The deduced amino acid sequence of these 2 isolates, along with those for FV3 (Mao et al. 1996), RRV (Bollinger et al. 1999), LMBV (Mao et al. 1999a), and LCDV (Tidonda \& Darai 1997), were aligned using the Megalign program within DNASTAR (Madison, WI). Amino acid residues differing from FV3 are indicated by shading. The nucleotide sequences of the RGV-9506 and -9807 have been deposited in GeneBank, accession No. AF192508 for RGV9506, and AF192509 for RGV-9807

composition, and DNA sequence was revealed. These results clearly indicate that the RGV isolates are essentially identical to each other and very similar to FV3. Moreover, in view of their marked similarity to FV3, it is likely that RGV represents a strain of FV3 rather than a unique viral species.

Iridoviruses are known to cause disease in amphibians, fish, molluscs and insects. The iridoviruses infecting amphibians and fish are classified within 2 genera (Ranavirus and Lymphocystivirus) within the family Iridoviridae (Williams et al. 2000). Comparison of the 3 RGV isolates with other iridoviruses identified the presence of characteristic iridovirus features including an icosahdedral virion, a replication process involving both the nucleus and cytoplasm, envelopment by budding from the plasma membrane, a viromatrix (i.e. viral assembly sites), and the presence of intracellular virions with paracrystalline arrays (Zhang et al. 1999b). However, although it is a straightforward task to identify members of the family Iridoviridae morphologically, and to distinguish members of the genus Ranavirus serologically, deciding whether or not a novel isolate is a unique viral species requires the use of molecular techniques (i.e. electrophoretic analysis of RFLP, PCR, and sequence analysis). Recently, Mao et al. (1997, 1999a,b), and Webby \& Kalmakoff (1998) characterized a number of iridoviruses isolated from various fish and insect species by analysis of viral pro- tein synthesis in infected cells, viral DNA RFLP, and sequence determination of the MCP and viral DNA methyltransferase genes. Using this approach, novel isolates can more readily be sorted into distinct viral species based on multiple alignment of the highly conserved MCP. Thus sequence analysis of Australian, European, American and Asian iridoviruses, isolated from different aquatic animal hosts, showed that all belonged to the genus Ranavirus (Mao et al. 1996, 1997, 1999a,b, Chinchar \& Mao 2000). In addition to taxonomic divisions based on the sequence of the MCP gene, other regions of the iridovirus genome have also been used. Thus, sensitive PCR tests have been developed to detect iridovirus infections in amphibians (Gould et al. 1995) and in marine fish infected with red sea bream iridovirus (Kurita et al. 1998, Oshima et al. 1998). Recently, Hyatt et al. (2000) used approaches similar to ours to analyze a panel of established and emerging iridovirus pathogens.

The shared characteristics revealed in the current study indicate that iridoviruses isolated from North America (FV3) and China (RGV) are similar, if not identical, and suggest that FV3 infections may be more serious and more widespread than previously thought. At present it is not clear if RGV is a newly emerged, more virulent strain of FV3, or whether the high mortality associated with RGV infection is a reflection of environmental factors that predispose to viral infection 
(i.e. animal husbandry conditions). An outbreak of severe disease among cultured tiger frogs in Thailand suggests that farm-raised frogs may be especially vulnerable to iridovirus infection (Kanchanakhan 1998). Perhaps environmental conditions within commercial frog farms has immunologically stressed these animals making them more susceptible to viral disease (Chinchar 2000). Since Rana grylio is present in the southeast United States and has been imported into China for farming purposes, it is possible that imported frogs harbored the virus and served as the focus for the initial infection. RGV isolates may provide the opportunity to determine how iridoviruses spread among amphibian populations and perhaps understand how FV3, long considered apathogenic in the species from which it is was originally isolated ( $R$. pipiens), causes severe disease in alternate hosts and in different environments. Further molecular characterization will be needed to answer these questions as well as ascertaining the impact of environmental stress on viral virulence.

Acknowledgements. This research was supported by grants (to Q.-Y.Z and J.-F.G) from the Major State Basic Research Program (No. G1999053908) and the 863 plan (No. 2001AA 620603 of the People's Republic of China, the State Key Laboratory of Freshwater Ecology and Biotechnology, the Chinese Academy of Sciences, Hubei Natural Science Foundation and the National Natural Science Foundation of China, and by awards (to V.G.C) from the US Department of Agriculture (No. 95-37204-2225) and the National Science Foundation (IBN-9977063). We thank Dr Steve Case (Director of the DNA Sequencing Facility, Department of Biochemistry, University of Mississippi Medical Center) for assistance with automated sequencing and analysis of these samples. In addition, the authors gratefully acknowledge the financial support (to J.M.) of the K. C. Wong Educational Fund (Hong Kong).

\section{LITERATURE CITED}

Ahne W, Schlotfeldt HJ, Thomsen I (1989) Fish viruses: isolation of an icosahedral cytoplasmic deoxyribovirus from sheatfish (Silurus glanis). J Vet Med Ser B 36:333-336

Ahne W, Bremont M, Hedrick RP, Hyatt AD, Whittington RJ (1997) Iridovirus association with epizootic haematopoietic necrosis (ENH) in aquaculture. World J Microbiol Biotechnol 13:367-373

Alves de Matos AP, Paperna I (1993) Ultrastructure of erythrocytic virus of the South African anuran Ptychadena anchietae. Dis Aquat Org 16(2):105-109

Bailey GS (1996) Ouchterlony double immunodiffusion. In: Walker JM (ed) The protein protocols. Humana Press, Totowa, NJ, p 749-752

Bollinger TK, Mao J, Schock D, Brigham RM, Chinchar VG (1999) Pathology, isolation, and preliminary molecular characterization of a novel iridoviurs from tiger salamanders in Saskatchewan. J Wildl Dis 35:413-429

Chinchar VG (2000) Ecology of viruses of cold-blooded vertebrates. In: Hurst C (ed) Viral ecology. Academic Press, San Diego, p 413-445
Chinchar VG, Mao J (2000) Molecular diagnosis of iridovirus infections in cold-blooded animals. Semin Avian Exotic Pet Med 9:27-35

Cullen BR, Owens L, Whittington RJ (1995) Experimental infection of Australian anurans (Limnodynastes terraereginae and Litoria latopalmata) with Bohle iridovirus. Dis Aquat Org 23(2):83-92

Cunningham AA, Langton TES, Bennett PM, Lewin JF, Drury SEN, Gough RE, MacGregor SK (1995) Pathological and microbiological findings from incidents of unusual mortality of the common frog (Rana temporaria). Philos Trans R Soc Lond B 351:1539-1557

Drury SEN, Gough RE, Cunningham AA (1995) Isolation an iridovirus-like agent from common frogs (Rana temporaria). Vet Rec 137:72-73

Essani K, Granoff A (1989) Properties of amphibian and piscine iridoviruses: a comparison. In: Ahne W (ed) Viruses of lower vertebrates. Springer-Verlag, Berlin, p 79-85

Fijan N, Matasin Z, Petrinec Z, Valpotic I, Zwillenberg LO (1991) Isolation of an iridovirus-like agent from the green frog (Rana esculenta L). Vet Arch Zagreb 3:151-158

Gould AR, Hyatt AD, Hengstberger SH, Whittington RJ, Coupar BEH (1995) A polymerase chain reaction (PCR) to detect epizootic haematopoietic necrosis virus and Bohle iridovirus. Dis Aquat Org 22(3):211-215

Granoff A, Came PE, and Breeze DC (1966) Virus and renal carcinoma of Rana pipiens. I. The isolation and properties of virus from normal and tumor tissue. Virology 29: 133-148

Granzow H, Weiland F, Fichtner D, Enzmann PJ (1997) Studies of the ultrastructure and morphogenesis of fish pathogenic viruses grown in cell culture. J Fish Dis 20:1-10

Gui JF, Lane WS, Fu XD (1994) A serine kinase regulates intracellular localization of splicing factors in the cell cycle. Nature 369:678-682

Hedrick RP, McDowell TS (1995) Properties of iridoviruses from ornamental fish. Vet Res (Paris) 26:423-427

Hedrick RP, McDowell TS, Ahne W, Torhy C, de Kinkelin P (1992) Properties of three iridovirus-like agents associated with systemic infectious of fish. Dis Aquat Org 13:203-209

Hengstberger SG, Hyatt AD, Speare R, Coupar BEH (1993) Comparison of epizootic haematopoietic necrosis and Bohle iridoviruses, recently isolated Australian iridoviruses. Dis Aquat Org 15(2):93-107

Hyatt AD, Gould AR, Zupanovic Z, Cunningham AA, Hengstberger S, Whittington RJ, Kattenbelt J, Coupar BEH (2000) Comparative studies of piscine and amphibian iridoviruses. Arch Virol 145:301-331

Jancovich JK, Davidson EW, Morado JF, Jacobs BL, Collins JB (1997) Isolation of a lethal virus from the endangered tiger salamander Ambystoma tigrinum stebbinsi. Dis Aquat Org 31:161-167

Jiang YL, Zhang QY, Liu H, LI Y, Li ZQ (1995) Study on cause of infectious diseases of penaeid shrimp in China. Acta Hydrobiol Sin 19(2):186-187 (in Chinese with English abstract)

Kanchanakhan S (1998) An ulcerative disease of the cultured tiger frog, Rana tigrinum, in Thailand: virological examination. AAHRI Newsl 7:1-2

Kurita J, Nakajima K, Hirono I, Aoki T (1998) Polymerase chain reaction (PCR) amplification of DNA of red sea bream iridovirus (RSIV). Fish Pathol 33(1):17-23

Langdon JS, Humphrey JD, Williams LM, Hyatt AD, Westbury HA (1986) First virus isolation from Australian fish: an iridovirus-like pathogen from redfin perch, Perca fluviatilis. J Fish Dis 9:263-268 
Langdon JS, Humphrey JD, Williams LM (1988) Outbreaks of an EHNV-like iridovirus in cultured rainbow trout, Salmo gairdneri, in Australia. J Fish Dis 11:93-96

Mao J, Tham TN, Gentry GA, Aubertin AM, Chinchar VG (1996) Cloning, sequence analysis and expression of the major capsid protein of the iridovirus frog virus 3 . Virology 216:431-436

Mao J, Hedrick RP, Chinchar VG (1997) Molecular characterization, sequence analysis, and taxonomic position of newly isolated fish iridoviruses. Virology 229:212-220

Mao J, Green DE, Fellers G, Chinchar VG (1999a) Molecular characterization of iridoviruses isolated from sympatric amphibians and fish. Virus Res 63:45-52

Mao JH, Wang J, Chinchar GD, Chinchar VG (1999b) Molecular characterization of a ranavirus isolated from largemouth bass Micropterus salmoides. Dis Aquat Org 37: 107-114

Matsuoka S, Inouye K, Nakajima K (1996) Cultured fish species affected by red sea bream iridoviral disease from 1991 to 1995. Fish Pathol 31:233-234

McGrogan DG, Ostland VE, Byrne PJ, Ferguson HW (1998) Systemic disease involving an iridovirus-like agent I cultured tilapia, Oreochromis niloticus L. - a case report. J Fish Dis 21:149-152

Moody NJG, Owens L (1994) Experimental demonstration of the pathogenicity of a frog virus, Bohle iridovirus, for a fish species, barramundi Lates calcarifer. Dis Aquat Org 18(2): 95-102

Nakajima K, Inouye K, Sorimachi M (1998) Viral diseases in cultured marine fish in Japan. Fish Pathol 33(4):181-188

Oshima S, Hata JI, Hirasawa N, Ohtaka T, Hirono I, Aoki T, Yamashita S (1998) Rapid diagnosis of red sea bream iridovirus infection using the polymerase chain reaction. Dis Aquat Org 32:87-90

Plumb JA, Grizzle JM, Young HE, Noyes AD (1996) An iridovirus isolated from wild largemouth bass. J Aquat Anim Health 8:265-270

Rodger HD, Kobs M, Macartney A, Frerichs GN (1997) Systemic iridovirus infection in freshwater angelfish, Pterophyllum scalare (Lichtenstein). J Fish Dis 20:69-72

Speare R, Smith JR (1992) An iridovirus-like agent isolated from the ornate burrowing frog in northern Australia. Dis Aquat Org 14:51-57

Tapiovaara H, Olesen NJ, Linden J, Rimaila-Parnanen E, von Bonsdorff C-H (1998) Isolation of an iridovirus from pikeperch Stizostedion lucioperca. Dis Aquat Org 32:185-193

Tidona CA, Darai G (1997) The complete DNA sequence of the lymphocystis disease virus. Virology 230:207-216

Uckun FM, Waddick KG, Mahajan S, Jun X, Takata M, Bolen J, Kurosaki T (1996) BTK as a mediator of radiationinduced apoptosis in DT-40 lymphoma B cells. Science 273:1096-1100

Watson LR, Groff JM, Hedrick RP (1998) Replication and pathogenesis of white sturgeon iridovirus (WSIV) in experimentally infected white sturgeon Acipenser transmontanus juveniles and sturgeon cell lines. Dis Aquat Org 32:173-184

Webby R, Kalmakoff J (1998) Sequence comparison of the major capsid protein gene from 18 diverse iridoviruses. Arch Virol 143:1949-1966

Editorial responsibility: Jo-Ann Leong,

Corvallis, Oregon, USA
Whittington RJ, Reddacliff LA, Marsh I, Kearns C, Zupanovic Z, Callinan RB (1999) Further observations on the epidemiology and spread of epizootic haematopoietic necrosis virus (EHNV) in farmed rainbow trout Oncorhynchus mykiss in southeastern Australia and a recommended sampling strategy for surveillance. Dis Aquat Org 35:125-130

Williams T, Chinchar G, Darai B, Hyatt A, Kalmakoff J, Seligy V (2000) Family Iridoviridae. In: van Regenmortel MHV, Fauquet CM, Bishop DHL, Carstens EB and 7 others (eds) Virus taxonomy: classification and nomenclature of viruses. 7th report of the International Committee on Taxonomy of Viruses. Academic Press, San Diego, p 167-182

Willis DB, Goorha R, Chinchar VG (1985) Macromoleclar synthesis in cells infected by frog virus 3. Curr Top Microbiol Immunol 116:77-106

Zhang QY (1997) Studies on viral diseases of special aquaculture animals. PhD thesis, Institute of Hydrobiology, Chinese Academy of Sciences, Wuhan, Hubei (in Chinese with English abstract)

Zhang QY, Li ZQ (1999) Three different viruses observed from the tissues of diseased mandarin fish Siniperca chuatsi. Chin Sci Bull 44(5):437-441

Zhang QY, Li ZQ, Jiang YL, Liang SC, Gui JF (1996a) Preliminary studies on virus isolation and cell infection from disease frogs Rana grylio. Acta Hydrobiol Sin 20:390-392 (in Chinese with English abstract)

Zhang QY, Li ZQ, Gui JF (1996b) Studies on viral pathogens from the special aquaculture animals and prevention biotechnology in China. The Symposium Committee (eds) Proceedings of Sino-American Symposium on Agricultural Research and Development in China. China Agriculture Press, Beijing, p 168-174 (in Chinese with English abstract).

Zhang QY, Li ZQ, Jiang YL, Liang SC, Gui JF (1997) Discovery of a virus pathogen from soft-shelled turtle Trionyx sinesis. Chin Sci Bull 42(6):503-506

Zhang QY, Jiang YL, Li Y, Li ZQ (1998) Isolation and characterization of nucleocapsids and enveloped virions of Penaeus monodon baculovirus. Acta Hydrobiol Sin 22(suppl):1-5

Zhang QY, Li ZQ, Gui JF (1999a) Cellular pathological studies on death of soft-shelled turtles induced by virus infection. Virol Sin 14(1):50-54 (in Chinese with English abstract)

Zhang QY, Li ZQ, Gui JF (1999b) Studies on morphogenesis and cellular interactions of Rana grylio virus (RGV) in an infected fish cell line. Aquaculture 175:185-197

Zhang QY, Li ZQ, Gui JF (2000a) Isolation of a lethal rhabdovirus from the cultured Chinese sucker Myхосурrinus asiaticus. Dis Aquat Org 42(1):1-9

Zhang QY, Li ZQ, Hu J (2000b) Serological detection for the Trionyx sinensis virus. Acta Hydrobiol Sin 24(4):361-365

Zupanovic Z, Lopez G, Hyatt AD, Green B, Bartran G, Parkes H, Whittington RJ, Speare R (1998a) Giant toad Bufo marinus in Australia and Venezuela have antibodies against 'ranaviruses'. Dis Aquat Org 32:1-8

Zupanovic Z, Musso C, Lopez G, Louriero CL, Hyatt AD, Hengstberger S, Robinson AJ (1998b) Isolation and characterization of iridoviruses from the giant toad Bufo marinus in Venezuela. Dis Aquat Org 33:1-9

Submitted: November 15, 1997; Accepted: March 3, 2001

Proofs received from author(s): December 16, 2001 